Environmental Pollution

November 2018, Volume 242, Part B, Pages 1598-1605

http://dx.doi.org/10.1016/i.envpol.2018.07.119

http://archimer.ifremer.fr/doc/00453/56424/

(C) 2018 Elsevier Ltd. All rights reserved.

\title{
A rapid quantitative fluorescence-based bioassay to study allelochemical interactions from Alexandrium minutum
}

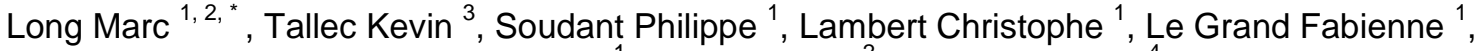 \\ Sarthou Géraldine ${ }^{1}$, Jolley Dianne ${ }^{2}$, Hégaret Helene ${ }^{4}$
}

${ }^{1}$ Laboratoire des Sciences de l'Environnement Marin (LEMAR), UMR 6539 CNRS UBO IRD IFREMER

-Institut Universitaire Européen de la Mer, Technopôle Brest-Iroise, Rue Dumont d'Urville, 29280,

Plouzané, France

${ }^{2}$ School of Chemistry, University of Wollongong, NSW, 2522, Australia

${ }^{3}$ Ifremer, Laboratoire des Sciences de l'Environnement Marin (LEMAR), UMR 6539

UBO/CNRS/IRD/Ifremer, 29280 Plouzané, France

* Corresponding author : Marc Long, email address : marc.florian.long@gmail.com

\begin{abstract}
:
Harmful microalgal blooms are a threat to aquatic organisms, ecosystems and human health. Toxic dinoflagellates of the genus Alexandrium are known to produce paralytic shellfish toxins and to release bioactive extracellular compounds (BECs) with potent cytotoxic, hemolytic, ichtyotoxic and allelopathic activity. Negative allelochemical interactions refer to the chemicals that are released by the genus Alexandrium and that induce adverse effects on the physiology of co-occurring protists and predators. Releasing BECs gives the donor a competitive advantage that may help to form dense toxic blooms of phytoplankton. However BECs released by Alexandrium minutum are uncharacterized and it is impossible to quantify them using classical chemical methods. Allelochemical interactions are usually quantified through population growth inhibition or lytic-activity based bioassays using a secondary target organism. However these bioassays require time (for growth or microalgal counts) and/or are based on lethal effects. The use of pulse amplitude modulation (PAM) fluorometry has been widely used to assess the impact of environmental stressors on phytoplankton but rarely for allelochemical interactions. Here we evaluated the use of PAM and propose a rapid chlorophyll fluorescence based bioassay to quantify allelochemical BECs released from Alexandrium minutum. We used the ubiquitous diatom Chaetoceros muelleri as a target species. The bioassay, based on sub-lethal effects, quantifies allelochemical activity from different samples (filtrates, extracts in seawater) within a short period of time $(2 \mathrm{~h})$. This rapid bioassay will help investigate the role of allelochemical interactions in Alexandrium bloom establishment. It will also further our understanding of the potential relationship between allelochemical activities and other cytotoxic activities from BECs. While this bioassay was developed for the species $A$. minutum, it may be applicable to other species producing allelochemicals and may provide further insights into the role and impact of allelochemical interactions in forming dense algal blooms and structuring marine ecosystems.
\end{abstract}




\section{Graphical abstract}

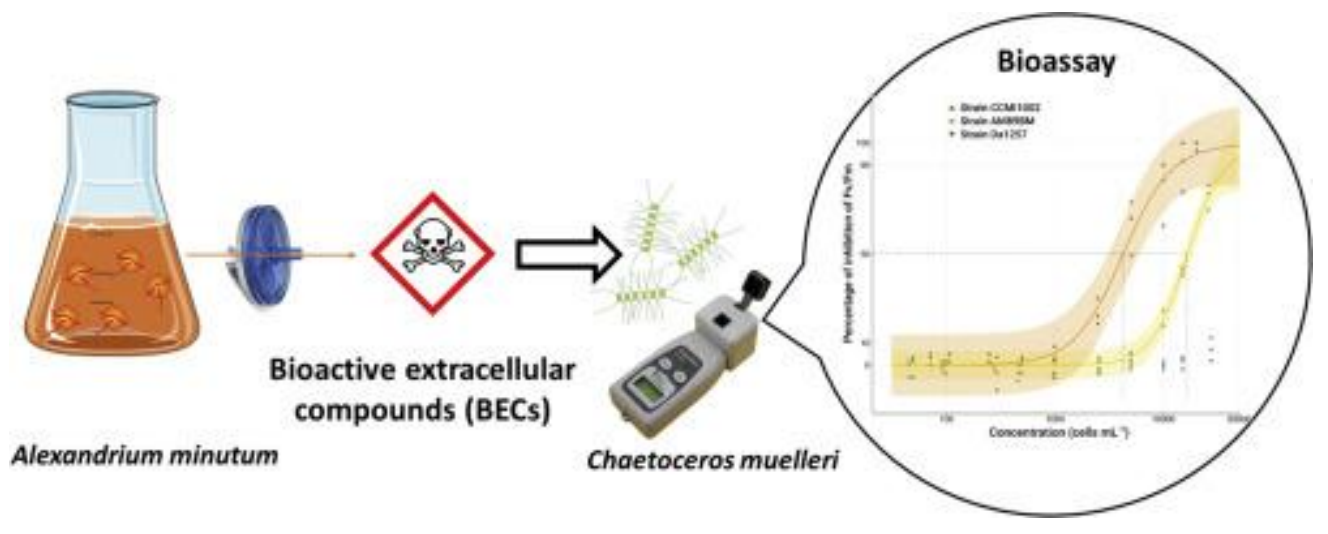

\section{Highlights}

- We developed a fast bioassay to screen Alexandrium bioactive extracellular compounds. The rapid quantification of allelopathic BECs is based on PAM fluorometry. This will help investigating links between allelo-, ichtyo-, hemo- and cytotoxicity. The bioassay will ease chemical identification of unknown bioactive compounds. The bioassay could be applied to algal cultures, extracts and environmental samples.

Keywords : Harmful algal bloom, Alexandrium, Allelopathy, Cytotoxicity, PAM fluorometry, Bioassay 


\section{1.INTRODUCTION}

60 Proliferation of microalgae is recognized as a major threat for marine ecosystems. Harmful

61 algal blooms can be responsible for toxic impacts on marine organisms and ecosystems and can

62 also be toxic to human. This involves public health risks (e.g. intoxications) and socio-economics

63 issues (e.g. loss of fisheries stock, fisheries closure). Dinoflagellates from the genus Alexandrium

64 have the potential to produce paralytic shellfish toxins but also to release uncharacterized bioactive

65 extracellular compounds (BECs) exhibiting allelochemical (Arzul et al., 1999; Lelong et al., 2011;

66 Tillmann et al., 2007), cytotoxic (Le Goïc et al., 2014), hemolytic (Arzul et al., 1999; Emura et al.,

67 2004), and ichtyotoxic activities (Borcier et al., 2017; Castrec et al., 2018; Mardones et al., 2015).

68 BECs from the genus Alexandrium affect a large range of marine protists including autotrophic and

69 heterotrophic organisms (Fistarol et al., 2004; Tillmann et al., 2008, 2007; Tillmann and Hansen,

$702009)$ by inducing cell lysis within hours.

71 Negative allelochemical interactions can be defined as the chemical release of compounds

72 by a protists that causes adverse effects on the physiology of other competing protists and predators,

73 thus giving the allelopathic species a competitive advantage. These negative interactions allow

74 protists to outcompete for resources (e.g. nutrient, light), induce prey immobilization, defend

75 against grazers and therefore are a key factor structuring plankton ecosystems (Legrand et al.,

76 2003). Allelochemical interactions are mediated by the production of BECs, named as

77 allelochemicals, released into the surrounding environment. BECs are poorly described (e.g.

78 chemical nature, mode of action) because of methodological and analytical difficulties, but are

79 mainly characterized by their activity spectra and effects on target cells: growth inhibition, death,

80 lysis, paralysis, inhibition of photosystem II etc. (Legrand et al., 2003). Short-term (minutes to

81 hour) deleterious effects were observed on the photosystem II of several phytoplankton species 
82 exposed to the genus Alexandrium (Tillmann et al., 2007) including the globally distributed diatom

83 Chaetoceros muelleri (Lelong et al., 2011, formerly named as Chaetoceros neogracile).

84 No standard and rapid methodology is available for the study of allelochemical interactions

85 in marine environments (Legrand et al., 2003). Development of bioassays would benefit the

86 allelochemical interactions research field by enabling the rapid confirmation and quantification of

87 allelochemical interactions. This would help to assess the role and relevance of these interactions

88 in plankton ecology. It would also greatly ease the isolation and characterization of unknown BECs

89 through bio-guided purification. Population growth inhibition (Chan et al., 1980; Paul et al., 2009;

90 Pushparaj et al., 1998) or enumeration of lysed cells (Hakanen et al., 2014; Ma et al., 2009;

91 Tillmann et al., 2007) are the most common parameters used in bioassays to demonstrate

92 allelochemical interactions but such techniques are time-consuming. According to the OECD

93 (2011) guidelines for testing chemicals, a growth inhibition test should be long enough to obtain a

94 16-fold population growth in control treatments (from few days to weeks depending on the target

95 species growth rate). Moreover, microscopic observations cannot be performed in every field

96 situation and distinction between viable and non-viable cells can be subjective because of a lack of

97 consensus on a microalgal death definition (Garvey et al., 2007). This is compounded by the fact

98 that the enumeration of lysed cells is based on lethal effects, although allelochemical interactions

99 in marine environments may not automatically imply cell lysis. Therefore, new rapid, quantitative

100 and sensitive methods are worth exploring to study allelochemical interactions.

101 Pulse amplitude modulatory (PAM) fluorometry is a method based on chlorophyll $a$

102 fluorescence that allows studying photosynthetic processes. PAM is frequently used to assess the 103 impact of environmental stressors (Barranguet et al., 2002; Juneau et al., 2003; Lippemeier et al., 104 1999; Miao et al., 2005), pollutants (see review from Ralph et al., 2007) or algicidal compounds 105 (Yang et al., 2017) on phytoplankton physiology, as it provides insights into phytoplankton 
"health". Maximum photosystem II quantum yield (Fv/Fm) is the optimal photosynthetic efficiency

107 and is one of the most popular and easiest parameter to interpret. PAM has the advantage of being 108 a rapid non-invasive and non-destructive method that can detect sub-lethal effects on photosystems.

109 Some devices can be portable, allowing rapid measurements useful in many situations. However, 110 only few studies report the measurement of chlorophyll $a$ fluorescence to demonstrate

111 allelochemical interactions (Blossom et al., 2014a; Borcier et al., 2017; Tillmann et al., 2007). The

112 lack of homogeneity in methods and summary parameters (e.g. single concentration measurement,

113 EC10, EC50: the effect concentrations inhibiting 10 or $50 \%$ of a physiologic parameter) prevent

114 comparisons between studies, highlighting the need of standardized bioassays.

115 The aim for this study was to assess the use of pulse amplitude modulation (PAM)

116 fluorometry in detecting allelochemical activity from A. minutum and to establish a rapid and 117 reliable fluorescence-based bioassay to quantify allelochemical activity from $A$. minutum samples.

118 The genus Chaetoceros was selected as a target species based on its known sensitivity to

119 Alexandrium spp. BECs (Arzul et al., 1999; Lelong et al., 2011; Weissbach et al., 2010), its ubiquity

120 in phytoplankton communities (Dalsgaard et al., 2003) and its co-occurrence with A. minutum

121 blooms (Chapelle et al., 2014; Klein et al., in prep). Moreover the genus Chaetoceros is a 122 microalgal model commonly used in ecotoxicological studies (Desai et al., 2006; Hii et al., 2009;

123 Hourmant et al., 2009). The bioassay was conceived to be applied to microalgal cultures, extracts

124 or field samples.

125 2. MATERIALS AND METHODS

1262.1 Algal culture

127 Three strains of the toxic dinoflagellate Alexandrium minutum were selected based upon 128 their different allelochemical activity. The strains AM89BM (isolated from a bloom in the Bay of 129 Morlaix, France) and CCMI1002 (isolated from a bloom in Ireland; Borcier et al., 2017) were 
130 chosen according to their cytotoxic potency (Arzul et al., 1999; Borcier et al., 2017; Lelong et al.,

131 2011). The strain Da1257 (isolated from a bloom in the Bay of Daoulas, France; Pousse et al.,

132 2017) was selected according to its low allelochemical potency. The cultures were grown in natural

133 filtered $(0.2 \mu \mathrm{m})$ seawater (collected in Argenton, France) supplemented with L1 medium (Guillard

134 and Hargraves, 1993) and maintained in exponential growth phase. The diatom Chaetoceros

135 muelleri (strain CCAP 1010-3, formerly named Chaetoceros neogracile or Chaetoceros sp.) was

136 cultured in filtered $(0.2 \mu \mathrm{m})$ artificial seawater (synthetic ocean water: Morel et al., 1979; Price et

137 al., 1989) supplemented with L1 medium (Guillard and Hargraves, 1993) and silica (1.06 x $10^{-4} \mathrm{M}$

138 final concentration). Both media were autoclaved. Microalgal cultures were maintained at $17 \pm 1^{\circ} \mathrm{C}$

139 under continuous light $\left(100-110 \mu \mathrm{mol}\right.$ photons $\left.\mathrm{m}^{-2} \mathrm{~s}^{-1}\right)$.

140 For each experiment, cultures of $C$. muelleri in exponential growth phase were used.

141 Diatoms were diluted with filtered artificial seawater to achieve $2 \times 10^{5}$ cells ml-1 (Lelong et al.,

142 2011) in the experiments and bioassays. Microalgal cells were counted and algal growth was

143 monitored using a FACSCalibur flow cytometer (Becton Dickinson, San Diego, CA, USA)

144 equipped with a blue laser (excitation $488 \mathrm{~nm}$ ). Concentrations (cells $\mathrm{mL}^{-1}$ ) were calculated from

145 the number of events per unit of time and the estimate of the FACSCalibur flow rate measured

146 according to Marie et al. (1999).

\section{$147 \quad 2.2$ BECs extraction}

148 BECs were separated from culture by filtration $(0.2 \mu \mathrm{m}$, acetate cellulose membrane,

149 16534-K, Sartorius) according to Lelong et al. (2011). Filtrates were prepared fresh in glass tubes

150 to avoid any loss to plastic during storage (Ma et al., 2009). The initial $A$. minutum culture

151 concentration, prior to filtration, was used to describe the potential allelochemical concentration of

152 each filtrate. Serial dilutions of this filtrate with filtered natural seawater were performed to obtain 
153 various concentrations. In the following text, the theoretical allelochemical concentration of each

154 filtrate is given by the concentration in A. minutum $\left(\right.$ cell $\mathrm{mL}^{-1}$ ) of the culture used to obtain the 155 filtrate.

158 photochemical efficiency, was measured by pulse amplitude modulation (PAM) fluorometry with 159 a handheld AquaPen-C AP-C 100 (Photon Systems Instruments, Drassov, Czech Republic) 160 equipped with a blue light $(455 \mathrm{~nm})$. In each experiment, algal samples were dark-adapted for at 161 least 20 minutes before measurement of fluorescence variables (F0, Fm). F0 is the initial

162 fluorescence intensity, Fm the maximal intensity under saturating light conditions ( 0.5 to $1 \mathrm{~s}$ at 1500

$163 \mu \mathrm{mol}$ photon $\mathrm{m}^{-2} \mathrm{~s}^{-1}$ ), and $\mathrm{Fv}=\mathrm{Fm}-\mathrm{F} 0$. Maximum quantum yield of photosystem II was then

164 calculated as followed: Fv/Fm (Strasser et al., 2000).

1652.4 Optimization of protocol

166 2.4.1 Sensitivity of $\mathrm{Fv} / \mathrm{Fm}$ to filtrate

167 In a first experiment, the kinetic impact of BECs upon the diatom's photosystem was

168 studied. Cells of C. muelleri ( $2 \times 10^{5}$ cells $\left.\mathrm{mL}^{-1}\right)$ were exposed to A. minutum (strain CCMI1002)

169 filtrate dilutions in filtered natural seawater, with final filtrate concentrations equivalent to 0,50 ,

170500,5000 and 50000 cells $\mathrm{mL}^{-1} . \mathrm{Fv} / \mathrm{Fm}$ was then measured every $30 \mathrm{~min}$ for the first $120 \mathrm{~min}$ of

171 exposure then every $60 \mathrm{~min}$ until $360 \mathrm{~min}$ of exposure. Results are expressed as the percentage of

$172 \mathrm{Fv} / \mathrm{Fm}$ inhibition compared to seawater control (see section 2.6).

$173 \quad 2.4 .2 \mathrm{Fv} / \mathrm{Fm}$ and FDA inhibition assay

174 The second experiment was performed to confirm that Fv/Fm is a good proxy of microalgal

175 metabolism in the bioassay. $\mathrm{Fv} / \mathrm{Fm}$ was compared to another proxy of primary metabolism, the

176 fluorescein diacetate-activity assay (Brookes et al., 2000; Franklin et al., 2001; Garvey et al., 2007). 
177 Fluorescein diacetate (FDA, Molecular probes, Invitrogen, Eugene, OR, USA) is a hydrophobic

178 fluorescent dye that permeates and stains cells exhibiting esterase activity, i.e. viable cells. Inside 179 the cells, FDA is cleaved by esterases and releases a fluorescent by-product (fluorescein; emission $180525 \mathrm{~nm}$ ) which is retained within the cells. Cells that are not stained in the presence of FDA do not 181 exhibit esterase activity and are considered as metabolically inactive (Supplementary figure 1).

182 FDA fluorescence in the diatoms was measured by flow cytometry (FACSCalibur) equipped with

183 a blue laser (excitation $488 \mathrm{~nm}$ ) through the detector of fluorescence FL1 (green emission filter 184 band pass, 530/30 nm). FDA staining protocol was optimized (Supplementary figures 2 and 3) for

185 C. muelleri and samples were stained (final concentration $=1.5 \mu \mathrm{M}$ ) for 10 min in dark prior to 186 flow-cytometric measurement, while samples for Fv/Fm measurement were put in the dark 20 min

187 before measurement. C. muelleri $\left(2 \times 10^{5}\right.$ cells $\left.\mathrm{mL}^{-1}\right)$ was exposed to $A$. minutum exudate filtrate 188 (strain CCMI1002) at concentrations (theoretical concentrations) equivalent to 500, 5000 and 50

189000 cells $\mathrm{mL}^{-1}$. Fv/Fm and FDA fluorescence were measured after $120 \mathrm{~min}$ of exposure.

1902.5 Bioassay procedure: comparison of A. minutum strains

191 2.5.1 Algal culturing

192 To compare allelochemical activity from three different $A$. minutum strains, cultures in 193 exponential growth phase were centrifuged $\left(280 \mathrm{~g}, 5 \mathrm{~min}, 17^{\circ} \mathrm{C}\right)$ and re-suspended in new L1 194 medium to reach final cell concentrations of $3 \times 10^{4}$ cells $\mathrm{mL}^{-1}$. These cultures were left to 195 equilibrate (release BECs) for $24 \mathrm{~h}$ prior to the commencement of bioassays.

196 2.5.2 Exposure

197 Triplicate cultures of $C$. muelleri in exponential growth phase (7 days old) were diluted 198 with filtered $(0.2 \mu \mathrm{m})$ synthetic ocean water to reach $2 \times 10^{5}$ cells $\mathrm{mL}^{-1}$ in the bioassay. Diatoms 199 were then exposed to dilutions of $A$. minutum culture filtrate (concentration $3 \times 10^{4}$ cells $\mathrm{mL}^{-1}$ ) 200 dilutions (in artificial seawater) in flow cytometry tubes ( $3 \mathrm{~mL}$ final volume), with filtrate 
201 concentrations equivalent to $0,50,100,300,500,1000,2500,5000,10000,15000$ and 25000

202 cells $\mathrm{mL}^{-1}$. Bioassay tubes were then incubated for $120 \mathrm{~min}$ : the first $100 \mathrm{~min}$ under light and the

203 last $20 \mathrm{~min}$ in the dark, before $\mathrm{Fv} / \mathrm{Fm}$ measurements. General bioassays procedures and test

204 conditions are summarized in Table 1.

2052.6 Calculations and graphics

206 The percentage of inhibition of maximum quantum yield was calculated as follow:

$$
\text { Inhibition }=\frac{F v / F m_{\text {control }}-F v / F m_{\text {filtrate }}}{F v / F m_{\text {control }}} \times 100
$$

Where $\mathrm{Fv} / \mathrm{Fm}_{\text {control }}$ and $\mathrm{Fv} / \mathrm{Fm}_{\text {filtrate }}$ were the maximum quantum yield of the diatom in

210 artificial seawater and exposed to A. minutum filtrate, respectively. All graphics were performed

211 using R software (R Foundation for Statistical Computing, Vienna, 2011). The effective

212 concentration inhibiting $10 \%\left(\mathrm{EC}_{10}\right), 50 \%\left(\mathrm{EC}_{50}\right)$ and $90 \%\left(\mathrm{EC}_{90}\right)$ of the $\mathrm{Fv} / \mathrm{Fm}$ as compared to

213 the control, were calculated from the dose-response curve based on the required A. minutum cell

214 density to achieve a filtrate toxicity to inhibit $\mathrm{Fv} / \mathrm{Fm}$. To calculate the effective concentrations, the

215 "Dose-Response Curve" package of R statistical analysis software was used (Gerhard et al., 2014).

216 The "Akaike's Information Criterion" was used to determine model suitability where multiple

217 models were tested (Koppel et al., 2017; Pinheiro and Bates, 2000). In all cases, a log-logistic

218 model with 3 parameters was favored. While inhibition data will be given in the manuscript, the

$219 \mathrm{Fv} / \mathrm{Fm}$ data are available in the supplementary files.

\section{3. RESULTS AND DISCUSSION}

\subsection{Sensitivity of $\mathrm{Fv} / \mathrm{Fm}$ to filtrate}

224 When C. muelleri was exposed to the lowest concentration of A. minutum filtrate (50 cells

$225 \mathrm{~mL}^{-1}$ ), Fv/Fm was not affected (Figure 1). For C. muelleri exposed to higher filtrate concentrations, 
$226 \mathrm{Fv} / \mathrm{Fm}$ was inhibited within the first 30 min corroborating the rapid toxicity mechanisms reported

227 by Lelong et al. (2011) and Tillmann et al. (2007). At a concentration of 500 cells mL ${ }^{-1}$, C. muelleri

$228 \mathrm{Fv} / \mathrm{Fm}$ inhibition varied between $6 \pm 2 \%$ and $24 \pm 6 \%$ during the six hours exposure. For filtrate

229 concentrations above 500 cells $\mathrm{mL}^{-1}, \mathrm{Fv} / \mathrm{Fm}$ inhibition in C. muelleri increased quickly within the

230 first $120 \mathrm{~min}$ then reached a plateau. When exposed to a theoretical cell concentration of 5000

231 cells $\mathrm{mL}^{-1}, \mathrm{Fv} / \mathrm{Fm}$ inhibition was $21 \pm 3 \%$ at $30 \mathrm{~min}$ and increased to a $100 \pm 0 \%$ inhibition at 120

$232 \mathrm{~min}$. With the highest filtrate concentration tested $\left(50000\right.$ cells $\left.\mathrm{mL}^{-1}\right), \mathrm{Fv} / \mathrm{Fm}$ inhibition was as

233 high as $62 \pm 4 \%$ after only 30 min of exposure and reached $100 \pm 0 \%$ inhibition within $90 \mathrm{~min}$.

234 For all tested concentration, the maximum inhibition and a plateau were reached within the first

235120 minutes. For the two highest concentrations, the complete inhibition was maintained for the

236 duration of the experiment (6 hours). Thus the following experiments (and bioassays) were

237 performed with an incubation time of 120 minutes. The measurement of an $\mathrm{EC}_{50}$ after only 120

238 minutes is of interest because the bioassay should be sufficiently short to avoid any loss of

239 allelochemical activity which can occur within a short time.

3.2 Fv/Fm and FDA inhibition assay

243 proxy of metabolic activity. The fluorescein diacetate (FDA) assay measures esterase activity, is

244 commonly used to determine phytoplankton viability (Agusti and Sánchez, 2002; Gentien et al.,

245 2007) and has been proven to be efficient with the genus Chaetoceros (Garvey et al., 2007). Results

246 showed that C. muelleri esterase activity was inhibited by the allelochemical filtrate, as the

247 proportion of metabolically inactive cells increased. This was observed by flow cytometry with a

248 decrease in the green (FL1) fluorescence (Supplementary figure 1). Three of the filtrate

249 concentrations $\left(500,5000\right.$ and 50000 cells $\left.\mathrm{mL}^{-1}\right)$ induced a loss in metabolic activity as measured

250 by both FDA staining and inhibition of $\mathrm{Fv} / \mathrm{Fm}$ (Figure 2). No increase in the proportion of 
251 metabolically inactive cells or decrease in Fv/Fm (compared to control) was observed when the

252 diatom was exposed to the filtrate concentration of 50 cells $\mathrm{mL}^{-1}$. When exposed to higher filtrate

253 concentrations, the inhibition of Fv/Fm was always higher than the percentage of metabolically

254 inactive cells measured with FDA staining. At a filtrate concentration of 500 cells $\mathrm{mL}^{-1}$, the 255 percentage of metabolically inactive cells was $11.5 \pm 0.2 \%$, while inhibition of Fv/Fm was of 19

$256 \pm 4 \%$. Once exposed to filtrate concentrations of 5000 and 50000 cells $\mathrm{mL}^{-1}$, the proportion of

257 metabolically inactive cells and inhibition of Fv/Fm were close to 88 and $100 \%$, respectively.

258 While the use of FDA allows an estimation of the percentage of metabolically active cells, Fv/Fm

259 is a measurement of the maximum photosystem II quantum yield (proxy of photosynthetic

260 metabolism), and both are good proxies as metabolic responses to A. minutum BECs with similar

261 dose-response behaviour (dynamic/trend).

2623.3 Bioassay: comparison of A. minutum strains

263 Inhibition of Fv/Fm in C. muelleri exposed to A. minutum culture filtrates was highly dependent

264 on the A. minutum strain. In addition Fv/Fm inhibition was also related to theoretical cell

265 concentration for the strains CCMI1002 and AM89BM. For those two strains, the relationship

266 between Fv/Fm inhibition and the (logarithmic) theoretical cell concentration was a sigmoidal

267 dose-response pattern (Figure 3). This dose-response curve enabled the calculation of the effective

268 concentrations inhibiting $\mathrm{Fv} / \mathrm{Fm}$ by $10 \%\left(\mathrm{EC}_{10}\right), 50 \%\left(\mathrm{EC}_{50}\right)$ and $90 \%\left(\mathrm{EC}_{90}\right)$ in the C. muelleri

269 populations (Table 2). The strain CCMI1002 induced the most adverse effects with an $\mathrm{EC}_{10}=1350$

$270 \pm 210$ cells $\mathrm{mL}^{-1}$ and an $\mathrm{EC}_{50}=4220 \pm 480$ cells $\mathrm{mL}^{-1}$. In comparison, to obtain a similar inhibition

271 of $\mathrm{Fv} / \mathrm{Fm}$ of the marine diatom Skeletonema costatum, a concentration of $13 \mu \mathrm{g} \mathrm{mL}-1$ of the

272 herbicide bentazon is necessary (Macedo et al., 2008). The strain AM89BM was four times less

273 toxic than the strain CCMI1002, with an $\mathrm{EC}_{10}=7710 \pm 349$ and an $\mathrm{EC}_{50}=16500 \pm 1700{\mathrm{cells} \mathrm{mL}^{-}}^{-}$

$274{ }^{1}$. These cell concentrations are well within the range of environmental A. minutum bloom 
275 concentrations, with reported densities as high as 41000 cells $\mathrm{mL}^{-1}$ in the bay of Brest, France

276 (Chapelle et al., 2015) highlighting that A. minutum blooms may impact plankton communities.

277 The results confirmed the difference in allelochemical potency of the strains observed by Borcier

278 et al. (2017) in a single-concentration bioassay, and also allowed us to precisely quantify the

279 allelochemical potency of each strain. The strain Da1257 had minimal effects on maximum

280 photosystem II quantum yield, with the highest cell concentration tested (27 400 cells mL $\left.{ }^{-1}\right)$ only

281 inducing an $\mathrm{Fv} / \mathrm{Fm}$ inhibition of $7 \pm 3 \%$ in C. muelleri., therefore effective concentrations (EC10,

282 EC50, EC90) could not be calculated. While this study validate the used of PAM fluorometry to

283 quantify allelopathic potency from A. minutum, the proposed bioassay may be applied to other

284 species of the genus Alexandrium. Many species from the genus Alexandrium induce lytic effects

285 and therefore could inhibit photosynthesis. For instance the species $A$. ostenfeldii inhibits Fv/Fm

286 (Tillmann et al., 2007). This bioassay could also be applied to other genus producing

287 allelochemicals such as the dinoflagellate Karlodinium venificum which BECs also inhibits

288 photosystem II quantum yield (Sheng et al., 2010). Moreover the variability in the sensitivity of

289 target species that has already been highlighted (Tillmann et al., 2008) could precisely be quantified

290 and compared with this bioassay.

291

292

\subsection{Precautions}

293 This study provides important information on how to properly assess a microagal bioassay using

294 PAM fluorometry. Fv/Fm is a sensitive physiologic parameter that responds to many different

295 environmental parameters (e.g. physiological state, light, temperature, various stress; Ralph et al., 296 2007) that can modify bioassay outcomes. Indeed, it is essential to be consistent in the protocol

297 (Table 1) and to perform controls to ensure that the inhibition is attributable to allelochemical

298 interactions. Alexandrium spp. BECs chemical features were partially described in previous studies 
299 and special care must be taken as the test conditions may greatly influence the outcomes of the

300 bioassay. To maintain biological activity of the BECs over time, plastics should be avoided,

301 especially for filtrate storage (Ma et al., 2009). When stored in glassware at a cool temperature $(\approx$

$3025^{\circ} \mathrm{C}$ ), allelochemical activity can be maintained for several weeks (Supplementary figure 4), and

303 up to 4 months when stored at $-30^{\circ} \mathrm{C}$ (Martens et al., 2016). Similarly, the choice of the filter

304 composition is important, because most filter membranes retained allelochemical activity

305 (unpublished data). Here we recommend the use of acetate cellulose or asymmetric

306 polyethersulfone (aPES) membrane filters.

3073.5 Bioassay applications

308 The ease of use and the rapid response of this bioassay makes it convenient for various

309 experiments. PAM techniques have many logistical advantages as they only require small sample

310 volumes (2 to $3 \mathrm{~mL}$ ), they are cheap, they can be used with environmentally relevant chlorophyll

311 concentrations and they are rapid (a few seconds per sample) compared to a classic growth

312 inhibition test or a lytic bioassay. Moreover the handled devices are practical, and allow the

313 bioassays to be performed in-situ. This enables a fast quantification of allelochemical potency from

314 various $A$. minutum samples: cultures, bio-guided purification of BECs, and field samples.

315 This bioassay can also be used for the purification of uncharacterized BECs (in prep.) produced by

316 the genus A. minutum. The choice of the bioassay used to identify BECs during fraction purification

317 is essential. During characterization of allelochemicals from A. catenella, Ma et al. $(2011,2009)$

318 preferred a phytoplankton (Rhodomonas salina) based bioassay rather than the usual bioassay with

319 brine shrimp and red blood cells (Arzul et al., 1999; Emura et al., 2004). Ma et al. (2011, 2009)

320 quantified allelochemical activity through microscopy counts of lysed $R$. salina cells, however the

321 present study highlights an easier and faster bioassay to follow bioactivity during purification of

322 these chemicals. 
$323 \quad 3.6$ A unique bioassay for other cytotoxic activities?

324 Exudates of A. minutum with allelochemical activity can have other toxic features. In a recent study,

325 Borcier et al. (2017) were able to distinguish between the contrasting effects of paralytic shellfish

326 toxins versus allelochemical exudates from A. minutum cultures over the great scallop Pecten

327 maximus thanks to a similar but single-concentration bioassay. Delayed shell growth, reduced gill

328 filtration, tissue damages and impaired escape behaviour when exposed to a predator were

329 specifically attributed to the allelochemical exudates. This research highlights the importance of

330 screening allelochemicals and studying the relationship between allelochemical interactions and

331 other cytotoxic activities. Other studies have revealed that allelochemical activity may be related

332 to other toxins (Arzul et al., 1999; Castrec et al., 2018; Le Goïc et al., 2014). This bioassay could

333 be used to investigate the links between allelochemical activity and other cytotoxic (e.g.

334 haemolytic, ichtyotoxic) activities through dose-response curves as performed by Blossom et al.

335 (2014b) to, for example, establish the relationship between allelochemical activity and

336 ichtyotoxicity from the prymnesiophyceae Prymnesium parvum.

3373.7 Potential for field application

338 Allelochemical interactions research has been mainly based on laboratory experiments and lacks

339 field reports to evaluate its role in plankton ecology. The bioassay developed here would be a useful

340 tool during A. minutum blooms to measure/quantify allelochemical activity within an

341 environmental matrix on a selected microalgal sample. The bioassay could be performed on in-situ

342 samples when monitoring a bloom directly or under laboratory conditions following an appropriate

343 sample storage (cooled glass container) to avoid any loss of activity. Moreover, measurement of a

344 non-lethal parameter, such as photosystem II quantum yield, would allow the detection of mild

345 effects. Indeed, non-lethal effects may reduce a cells ability to cope with other stress and indeed to

346 compete with other species. 


\section{CONCLUSION}

348 This study has demonstrated that the fluorescence-based bioassay can provide a fast and sensitive

349 measure of allelochemical activity from various samples: culture filtrates and extracts resuspended

350 in seawater. The developed bioassay successfully used the diatom C. muelleri as a target cell and

351 enabled the quantification of allelochemical activity from three different $A$. minutum strains.

352 Accurate quantification of allelochemical activity revealed a high variability in allelochemical

353 potency of different strains from the same species. This bioassay may facilitate further research to

354 broaden our understanding of allelochemical interactions from Alexandrium genus (purification

355 and characterization, toxicity mechanisms, ecologic role). The information in this study also

356 provides protocols to applying this technique to the study of allelochemical potency from other

357 microalgal models.

\section{ACKNOWLEDGEMENTS}

The authors would like to warmly thank N. Le Goïc and R. Guillonneau for their technical help as well as D. Koppel and G. Macoustra for their help with statistics. This study was carried out with the financial support of the National Research Agency (ANR) "ACCUTOX" project 13-CESA0019 (2013-2017). This project was financially supported by the Région Bretagne, the University of Wollongong and the LabexMer.

\section{REFERENCES}

Agusti, S., Sánchez, M.C., 2002. Cell variability in natural phytoplankton communities quantified by a membrane permeability probe. Limnol. Ocean. 47, 818-828.

Arzul, G., Seguel, M., Guzman, L., Denn, E.E., 1999. Comparison of allelopathic properties in 3 toxic Alexandrium species. J. Exp. Bot. 232, $285-295$.

Barranguet, C., Plans, M., van der Grinten, T.E., Sinke, J.J., Admiraal, W., 2002. Development of photosynthetic biofilms affected by dissolved and sorbed copper in a eutrophic river. Environ. Toxicol. Chem. 21, 1955-65.

Blossom, H.E., Andersen, N.G., Rasmussen, S.A., Hansen, P.J., 2014a. Stability of the intra- and extracellular toxins of Prymnesium parvum using a microalgal bioassay. Harmful Algae 32, 11-21. doi:10.1016/j.hal.2013.11.006

Blossom, H.E., Rasmussen, S.A., Andersen, N.G., Larsen, T.O., Nielsen, K.F., Hansen, P.J., 2014b. Prymnesium parvum revisited: Relationship between allelopathy, ichthyotoxicity, and chemical profiles in 5 strains. Aquat. Toxicol. 157, 159-166. 
doi:10.1016/j.aquatox.2014.10.006

Borcier, E., Morvezen, R., Boudry, P., Miner, P., Charrier, G., Laroche, J., Hegaret, H., 2017. Effects of bioactive extracellular compounds and paralytic shellfish toxins produced by Alexandrium minutum on growth and behaviour of juvenile great scallops Pecten maximus. Aquat. Toxicol. 184, 142-154. doi:10.1016/j.aquatox.2017.01.009

Brookes, J.D., Geary, S.M., Ganf, G.G., Burch, M.D., 2000. Use of FDA and flow cytometry to assess metabolic activity as an indicator of nutrient status in phytoplankton. Mar. Freshw. Res. 51, 817-823. doi:10.1071/MF00048

Castrec, J., Soudant, P., Payton, L., Tran, D., Miner, P., Lambert, C., Goïc, N. Le, Huvet, A., Quillien, V., Boullot, F., Amzil, Z., Hégaret, H., Fabioux, C., 2018. Bioactive extracellular compounds produced by the dinoflagellate Alexandrium minutum are highly detrimental for oysters. Aquat. Toxicol. 199, 188-198. doi:10.1016/j.aquatox.2018.03.034

Chan, A.T., Andersen, R.J., Le Blanc, M.J., Harrison, P.J., 1980. Algal plating as a tool for investigating allelopathy among marine microalgae. Mar. Biol. 59, 7-13. doi:10.1007/BF00396977

Chapelle, A., Le Bec, C., Le Gac, M., Labry, C., Amzil, Z., Guillou, L., Dreanno, C., Klouch, K., Siano, R., Pineau, L., Savar, V., Destombe, C., Dia, A., Lazure, P., Petton, S., Plus, M., Le Brun, L., Abernot, C., Duval, A., Doner, A., Gouriou, J., Gal, D. Le, Caradec, F., Andrieux, F., Malestroit, P., 2014. Étude sur la prolifération de la microalgue Alexandrium minutum en rade de Brest 61 .

Chapelle, A., Le Gac, M., Labry, C., Siano, R., Quere, J., Caradec, F., Le Bec, C., Nezan, E., Doner, A., Gouriou, J., 2015. The Bay of Brest (France), a new risky site for toxic Alexandrium minutum blooms and PSP shellfish contamination. Harmful Algae News 51, 45.

Dalsgaard, J., John, M. St., Kattner, G., Müller-Navarra, D., Hagen, W., 2003. Fatty acid trophic markers in the pelagic marine environment, in: Southward, A.J., Tyler, P.A., Young, C.M., Fuiman, L.A. (Eds.), Advances in Marine Biology. Elsevier, pp. 227-318. doi:10.1017/CBO9781107415324.004

Desai, S.R., Verlecar, X.N., Nagarajappa, Goswami, U., 2006. Genotoxicity of cadmium in marine diatom Chaetoceros tenuissimus using the alkaline Comet assay. Ecotoxicology 15, 359-363. doi:10.1007/s10646-006-0076-2

Emura, A., Matsuyama, Y., Oda, T., 2004. Evidence for the production of a novel proteinaceous hemolytic exotoxin by dinoflagellate Alexandrium taylori. Harmful Algae 3, 29-37. doi:10.1016/j.hal.2003.08.004

Fistarol, G.O., Legrand, C., Selander, E., Hummert, C., Stolte, W., Granéli, E., 2004. Allelopathy in Alexandrium spp.: Effect on a natural plankton community and on algal monocultures. Aquat. Microb. Ecol. 35, 45-56. doi:10.3354/ame035045

Franklin, N.M., Adams, M.S., Stauber, J.L., Lim, R.P., 2001. Development of an improved rapid enzyme inhibition bioassay with marine and freshwater microalgae using flow cytometry. Arch. Environ. Contam. Toxicol. 40, 469-480. doi:10.1007/s002440010199

Garvey, M., Moriceau, B., Passow, U., 2007. Applicability of the FDA assay to determine the viability of marine phytoplankton under different environmental conditions. Mar. Ecol. Prog. Ser. 352, 17-26. doi:10.3354/meps07134

Gentien, P., Lunven, M., Lazure, P., Youenou, A., Crassous, M.P., 2007. Motility and autotoxicity in Karenia mikimotoi (Dinophyceae). Philos. Trans. R. Soc. Lond. B. Biol. Sci. 362, 19371946. doi:10.1098/rstb.2007.2079

Gerhard, D., Bremer, M., Ritz, C., 2014. Estimating marginal properties of quantitative real-time 
PCR data using nonlinear mixed models. Biometrics 70, 247-254. doi:10.1111/biom.12124 Guillard, R.R.L., Hargraves, P.E., 1993. Stichochrysis immobilis is a diatom, not a chrysophyte. Phycologia 32, 234-236. doi:10.2216/i0031-8884-32-3-234.1

Hakanen, P., Suikkanen, S., Kremp, A., 2014. Allelopathic activity of the toxic dinoflagellate Alexandrium ostenfeldii: Intra-population variability and response of co-occurring dinoflagellates. Harmful Algae 39, 287-294. doi:10.1016/j.hal.2014.08.005

Hii, Y.S., Shia, K.L., Chuah, T.S., Hing, L.S., 2009. Physiological responses of Chaetoceros sp. and Nannochloropsis sp to short-term 2, 4-D, dimethylamine and endosulfan exposure. Aquat. Ecosyst. Health Manag. 12, 375-389. doi:10.1080/14634980903347662

Hourmant, A., Amara, A., Pouline, P., Durand, G., Arzul, G., Quiniou, F., 2009. Effect of bentazon on growth and physiological responses of marine diatom: Chaetoceros gracilis. Toxicol. Mech. Methods 19, 109-115. doi:10.1080/15376510802290892

Juneau, P., Lawrence, J.E., Suttle, C.A., Harrison, P.J., 2003. Effects of viral infection on photosynthetic processes in the bloom-forming alga Heterosigma akashiwo. Aquat. Microb. Ecol. 31, 9-17. doi:10.3354/ame031009

Koppel, D.J., Gissi, F., Adams, M.S., King, C.K., Jolley, D.F., 2017. Chronic toxicity of five metals to the polar marine microalga Cryothecomonas armigera - Application of a new bioassay. Environ. Pollut. 228, 211-221. doi:10.1016/j.envpol.2017.05.034

Le Goïc, N., Hégaret, H., Boulais, M., Béguel, J.P., Lambert, C., Fabioux, C., Soudant, P., 2014. Flow cytometric assessment of morphology, viability, and production of reactive oxygen species of Crassostrea gigas oocytes. Application to Toxic dinoflagellate (Alexandrium minutum) exposure. Cytom. Part A 85, 1049-1056. doi:10.1002/cyto.a.22577

Legrand, C., Rengefors, K., Fistarol, G.O., Granéli, E., 2003. Allelopathy in phytoplankton biochemical, ecological and evolutionary aspects. Phycologia 42, 406-419. doi:10.2216/i0031-8884-42-4-406.1

Lelong, A., Haberkorn, H., Le Goïc, N., Hégaret, H., Soudant, P., 2011. A new insight into allelopathic effects of Alexandrium minutum on photosynthesis and respiration of the diatom Chaetoceros neogracile revealed by photosynthetic-performance analysis and flow cytometry. Microb. Ecol. 62, 919-930. doi:10.1007/s00248-011-9889-5

Lippemeier, S., Hartig, P., Colijn, F., 1999. Direct impact of silicate on the photosynthetic performance of the diatom Thalassiosira weissflogii assessed by on- and off-line PAM fluorescence measurements. J. Plankton Res. 21, 269-283. doi:10.1093/plankt/21.2.269

Ma, H., Krock, B., Tillmann, U., Cembella, A., 2009. Preliminary characterization of extracellular allelochemicals of the toxic marine dinoflagellate Alexandrium tamarense using a Rhodomonas salina bioassay. Mar. Drugs 7, 497-522. doi:10.3390/md7040497

Ma, H., Krock, B., Tillmann, U., Muck, A., Wielsch, N., Svatoš, A., Cembella, A., 2011. Isolation of activity and partial characterization of large non-proteinaceous lytic allelochemicals produced by the marine dinoflagellate Alexandrium tamarense. Harmful Algae 11, 65-72. doi:10.1016/j.hal.2011.07.004

Macedo, R.S., Lombardi, A.T., Omachi, C.Y., Rörig, L.R., 2008. Effects of the herbicide bentazon on growth and photosystem II maximum quantum yield of the marine diatom Skeletonema costatum. Toxicol. Vitr. 22, 716-722. doi:10.1016/j.tiv.2007.11.012

Mardones, J.I., Dorantes-Aranda, J.J., Nichols, P.D., Hallegraeff, G.M., 2015. Fish gill damage by the dinoflagellate Alexandrium catenella from Chilean fjords: Synergistic action of ROS and PUFA. Harmful Algae 49, 40-49. doi:10.1016/j.hal.2015.09.001

Marie, D., Brussaard, C.P.D., Thyrhaug, R., Bratbak, G., Vaulot, D., 1999. Enumeration of marine viruses in culture and natural samples by flow cytometry. Appl. Environ. Microbiol. 
65, 45-52.

Martens, H., Van de Waal, D.B., Brandenburg, K.M., Krock, B., Tillmann, U., 2016. Salinity effects on growth and toxin production in Alexandrium ostenfeldii from The Netherlands. J. Plankton Res. 00, 1-15. doi:10.1093/plankt/fbw053

Miao, A.-J., Wang, W.-X., Juneau, P., 2005. COmparison OF Cd , Cu , and $\mathrm{Zn}$ toxic effects on four marine phytoplankton by pulse-amplitude-modulated fluorometry. Environ. Toxicol. Chem. 24, 2603-2611. doi:10.1897/05-009R.1

Morel, F.M.M., Rueter, J.G., Anderson, D.M., Guillard, R.R.L., 1979. Aquil: a chemically defined phytoplankton culture medium for trace metal tudies. J. Phycol. doi:10.1111/j.15298817.1979.tb02976.x

OECD, 2011. OECD guidelines for the testing of chemicals. Test No. 201: Freshwater Alga and Cyanobacteria, Growth Inhibition Test, OECD publishing.

Paul, C., Barofsky, A., Vidoudez, C., Pohnert, G., 2009. Diatom exudates influence metabolism and cell growth of co-cultured diatom species. Mar. Ecol. Prog. Ser. 389, 61-70. doi: $10.3354 /$ meps 08162

Pinheiro, J., Bates, D., 2000. Mixed-effects Models in S and S-PLUS. Springer Sci. Bus. Media.

Pousse, É., Flye-Sainte-Marie, J., Alunno-Bruscia, M., Hégaret, H., Jean, F., 2017. Sources of paralytic shellfish toxin accumulation variability in the Pacific oyster Crassostrea gigas. Toxicon. doi:10.1016/j.toxicon.2017.12.050

Price, N.M., Harrison, G.I., Hering, J.G., Hudson, R.J., Nirel, P.M. V., Palenik, B., Morel, F.M.M., 1989. Preparation and Chemistry of the Artificial Algal Culture Medium Aquil. Biol. Oceanogr. 6, 443-461. doi:10.1080/01965581.1988.10749544

Pushparaj, B., Pelosi, E., Jüttner, F., 1998. Toxicological analysis of the marine cyanobacterium Nodularia harveyana. J. Appl. Phycol. 10, 527-530. doi:10.1023/A:1008080615337

R Foundation for Statistical Computing, Vienna, A.I. 3-900051-07-0, 2011. R Development Core Team. R A Lang. Environ. Stat. Comput. 55, 275-286.

Ralph, P.J., Smith, R.A., Macinnis-Ng, C.M.O., Seery, C.R., 2007. Use of fluorescence-based ecotoxicological bioassays in monitoring toxicants and pollution in aquatic systems: Review. Toxicol. Environ. Chem. 89, 589-607. doi:10.1080/02772240701561593

Sheng, J., Malkiel, E., Katz, J., Adolf, J.E., Place, A.R., 2010. A dinoflagellate exploits toxins to immobilize prey prior to ingestion. Proc. Natl. Acad. Sci. 107, 2082-2087. doi:10.1073/pnas.0912254107

Strasser, J.R., Srivastava, A., Tsimilli-Michael, M., 2000. The fluorescence transient as a tool to characterize and screen photosynthetic samples, in: Probing Photosynthesis: Mechanism, Regulation \& Adaptation. pp. 445-483.

Tillmann, U., Alpermann, T., John, U., Cembella, A., 2008. Allelochemical interactions and shortterm effects of the dinoflagellate Alexandrium on selected photoautotrophic and heterotrophic protists. Harmful Algae 7, 52-64. doi:10.1016/j.hal.2007.05.009

Tillmann, U., Hansen, P.J., 2009. Allelopathic effects of Alexandrium tamarense on other algae: Evidence from mixed growth experiments. Aquat. Microb. Ecol. 57, 101-112. doi: $10.3354 / \mathrm{ame} 01329$

Tillmann, U., John, U., Cembella, A., 2007. On the allelochemical potency of the marine dinoflagellate Alexandrium ostenfeldii against heterotrophic and autotrophic protists. J. Plankton Res. 29, 527-543. doi:10.1093/plankt/fbm034

Weissbach, A., Tillmann, U., Legrand, C., 2010. Allelopathic potential of the dinoflagellate Alexandrium tamarense on marine microbial communities. Harmful Algae 10, 9-18. doi:10.1016/j.hal.2010.05.007 
520 Yang, K., Chen, Q., Zhang, D., Zhang, H., Lei, X., Chen, Z., Li, Y., Hong, Y., Ma, X., Zheng, W., 521 Tian, Y., Zheng, T., Xu, H., 2017. The algicidal mechanism of prodigiosin from Hahella sp. KA22 against Microcystis aeruginosa. Sci. Rep. 7, 7750. doi:10.1038/s41598-017-08132-5 


\section{FIGURES}

526
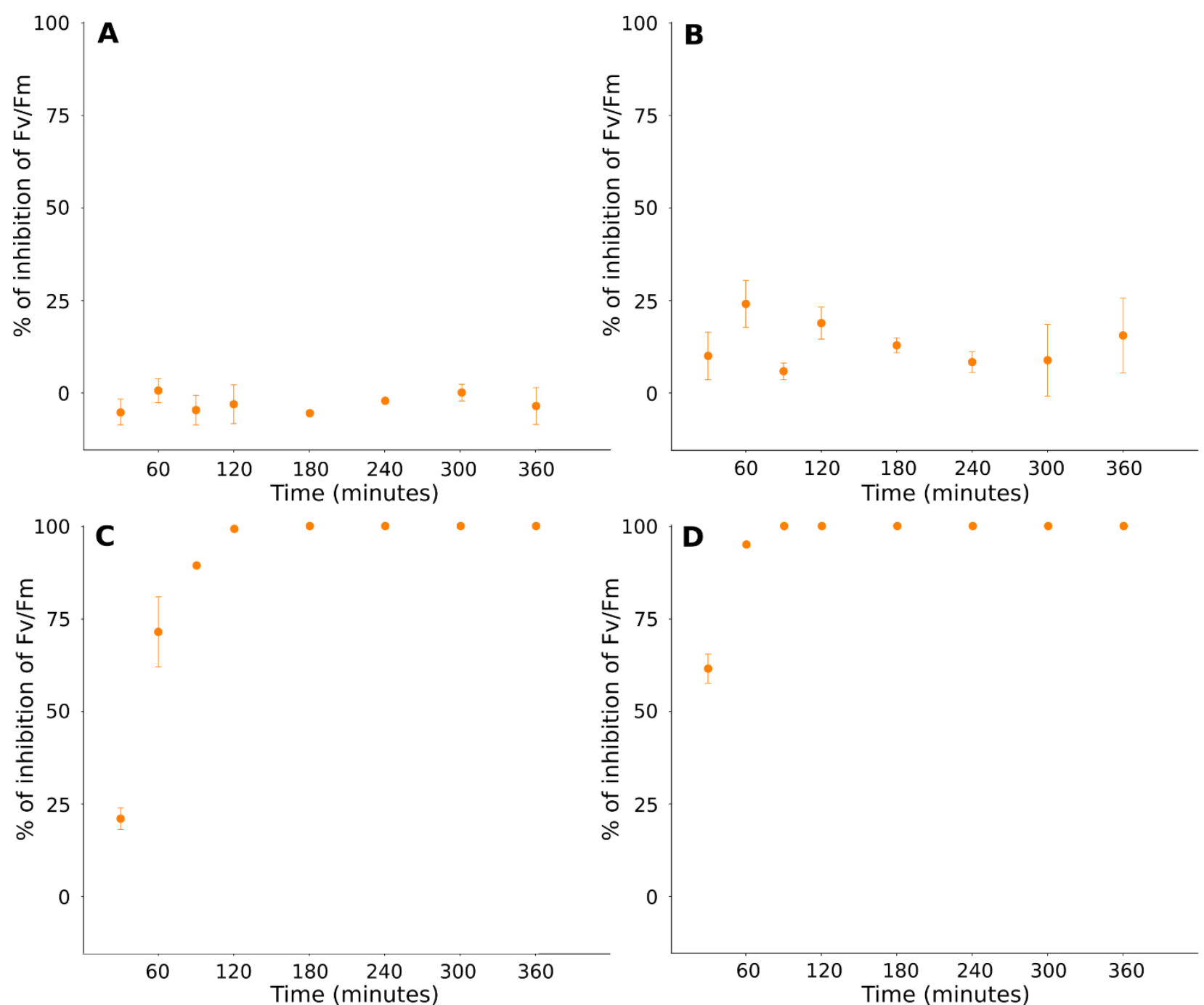

528 Figure 1: Kinetics of $C$. muelleri Fv/Fm inhibition when exposed to A. minutum (CCMI1002)

529 filtrate at different theoretical cell concentrations of A: 50 cells mL ${ }^{-1}$, B: 500 cells mL $\mathrm{mL}^{-1}, \mathrm{C}: 5000$

530 cells $\mathrm{mL}^{-1}$ and $\mathrm{D}: 50000$ cells $\mathrm{mL}^{-1}$. Results are expressed as mean \pm standard deviation. 

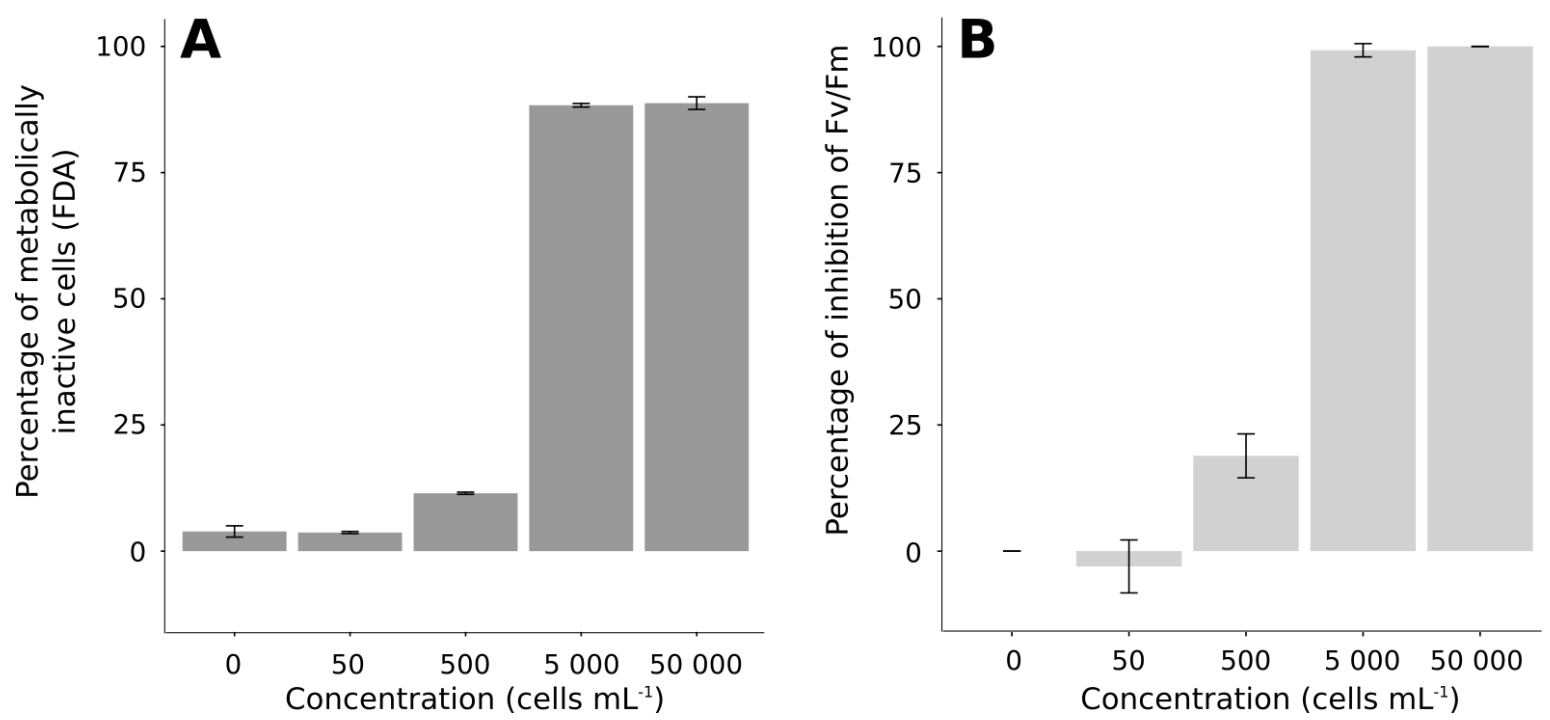

531

Figure 2: Effects of A. minutum (CCMI1002) filtrate on A) the percentage of metabolically inactive cells (FDA) and $\mathrm{B}$ ) the percentage of inhibition of $\mathrm{Fv} / \mathrm{Fm}$ of the diatom $C$. muelleri at different 534 theoretical cell concentrations $\left(0,50,500,5000\right.$ and 50000 cells mL $\left.{ }^{-1}\right)$ after $120 \mathrm{~min}$ of exposure. 535 Results are expressed as mean \pm standard deviation. $\mathrm{N}=3$. 


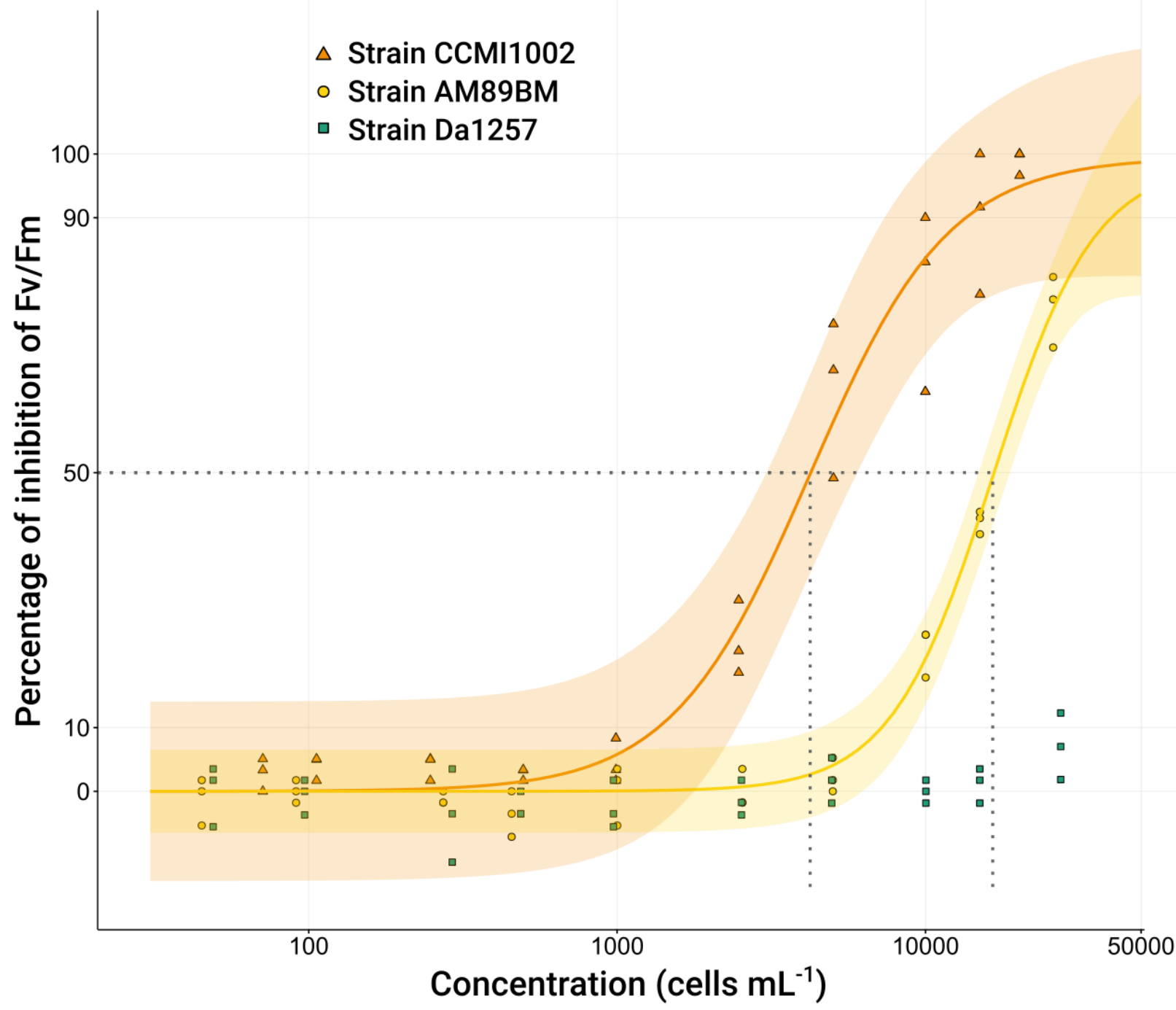

Figure 3: Inhibition of C. muelleri maximum photosystem II quantum yield (Fv/Fm) by A. minutum 538 filtrates from different strains. Dots represent the percentage of inhibition of $\mathrm{Fv} / \mathrm{Fm}$ as compared 539 to controls, as a function of filtrate dilution. The diatoms were exposed to strain CCMI1002 (red 540 triangle), strain AM89BM (yellow circle) and strain Da1257 (green squares) ( $\mathrm{n}=3$ ). For both 541 curves, the ribbon represents the $95 \%$ confidence interval from the log-logistic model. $\mathrm{EC}_{50}$ are 542 indicated by the dotted lines. 


\section{TABLES}

546

547 Table 1: Culturing and allelochemical interaction test conditions

\begin{tabular}{|c|c|}
\hline \multicolumn{2}{|r|}{ Allelopathic sample } \\
\hline Type of sample & Culture filtrates $(0.2 \mu \mathrm{m}$, acetate cellulose) \\
\hline Storage & Glass containers, no plastic \\
\hline Concentration & Series of dilutions \\
\hline \multicolumn{2}{|r|}{ Target cells } \\
\hline Species & C. muelleri \\
\hline Strain & CCAP $1010-3$ \\
\hline Culture media & L1 media supplemented with silica in synthetic ocean water \\
\hline Culturing temperature & $17 \pm 1^{\circ} \mathrm{C}$ \\
\hline Culturing light condition & $100-110 \mu \mathrm{mol}$ photon $\mathrm{m}^{-2} \mathrm{~s}^{-1}$ \\
\hline Culturing light cycle & Continuous light \\
\hline Physiological state & Exponential growth rate \\
\hline Concentration in bioassay & $2 \times 10^{5}$ cells $\mathrm{mL}^{-1}$ \\
\hline
\end{tabular}

\section{Allelopathic test condition}

Test conditions

Test duration

Test temperature

Test light condition

Test chamber

Test solution volume

Endpoint
Static, well homogenized

120 minutes

Ambient temperature $\left(\approx 20^{\circ} \mathrm{C}\right)$

100 minutes under light then 20 minutes in dark (dark-adapted sample)

Flow-cytometric tubes (Polystyrene), cuvettes (Polymethyl methacrylate)

2-3 $\mathrm{mL}$

Maximum photosystem II quantum yield (Fv/Fm)

Table 2: Effective filtrate concentrations (cells mL-1) inhibiting $10 \%$ (EC10), $50 \%$ (EC50) and $55190 \%$ (EC90) of C. muelleri Fv/Fm for three different A. minutum strains. "NC" indicate that no 552 value could be calculated. Results are expressed as mean \pm standard error $(n=3)$.

553

\begin{tabular}{llcc}
\hline Strain & EC10 & EC50 & EC90 \\
\hline CCMI1002 & $1350 \pm 210$ & $4220 \pm 480$ & $13160 \pm 3980$ \\
AM89BM & $7710 \pm 340$ & $16510 \pm 1690$ & $38020 \pm 7780$ \\
Da1257 & NC & NC & NC \\
\hline
\end{tabular}

555

556 

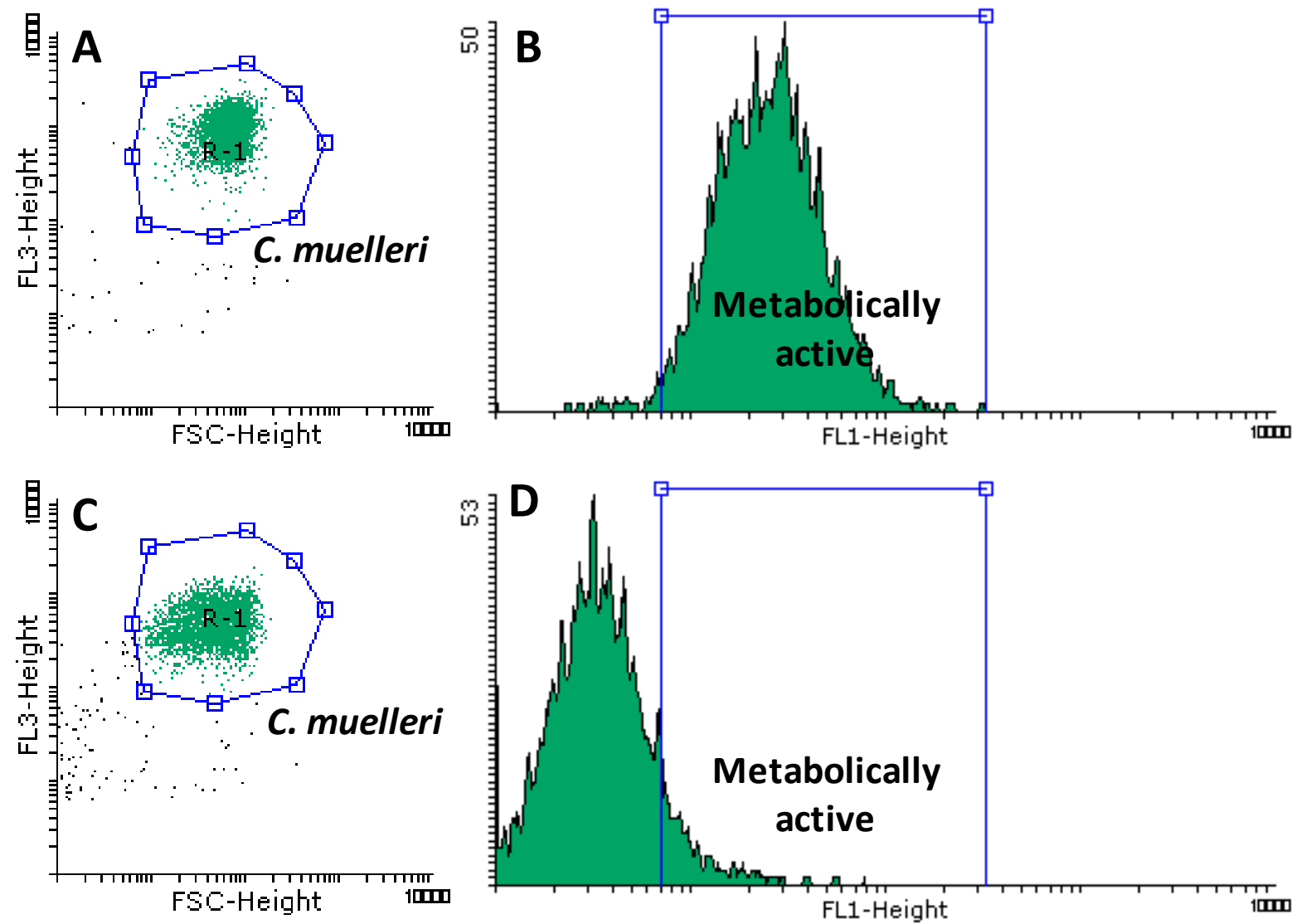

Supplementary figure 1: Cytograms of Chaetoceros muelleri culture: health cells (A and B) and cells exposed to Alexandrium minutum filtrate (C and D). The microalgal population $(R-1)$ is illustrated in green on dot plots $A$ and $C$ representing red fluorescence (FI3-Height) vs. forward scatter (FSC-Height). The histograms B and D represent the count of cells vs. their green fluorescence (FI1Height) after FDA staining. Metabolically active cells (high green fluorescence) are within the blue rectangle while metabolically

563 inactive cells (low green fluorescence) are on the left of the blue rectangle. 


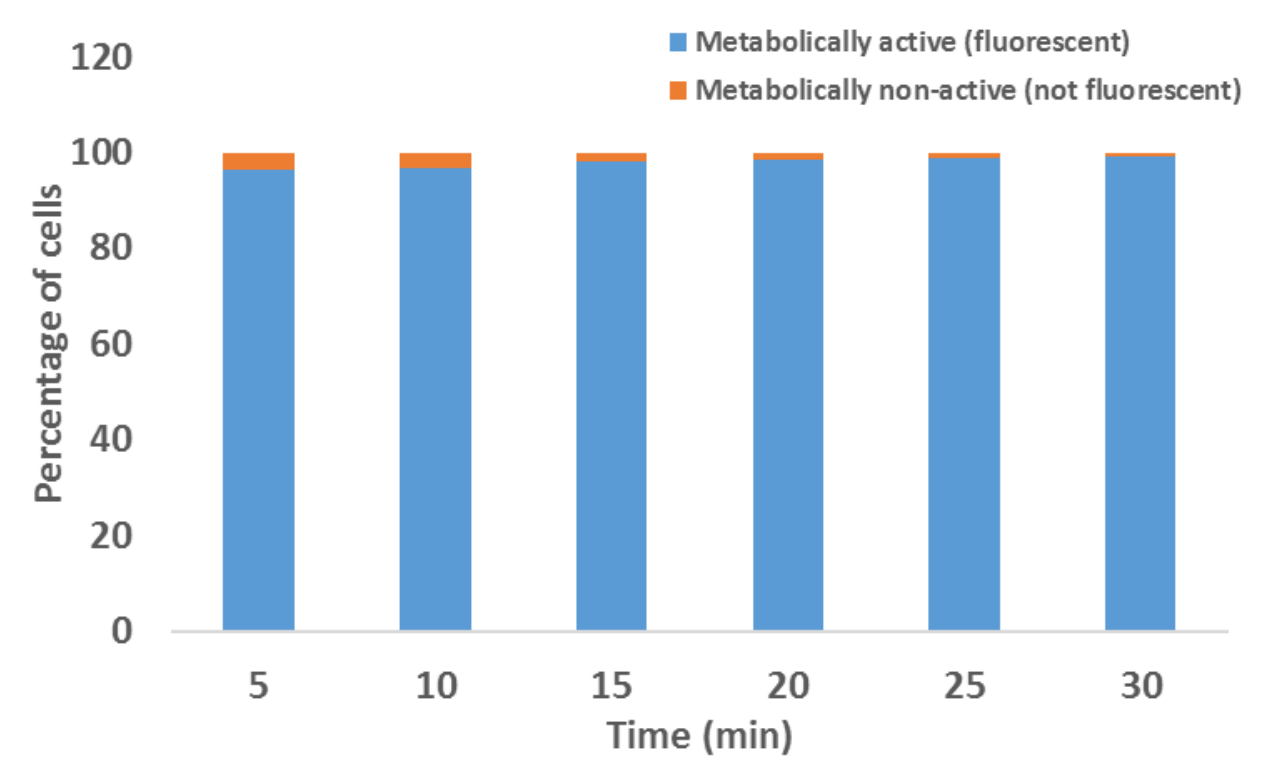

Supplementary figure 2: Percentage of metabolically active (fluorescent cells; in blue) and metabolically inactive (not fluorescent; in orange) C. muelleri cells stained with FDA for 5, 10, 15, 20, 25 and $30 \mathrm{~min}$ (in seawater).

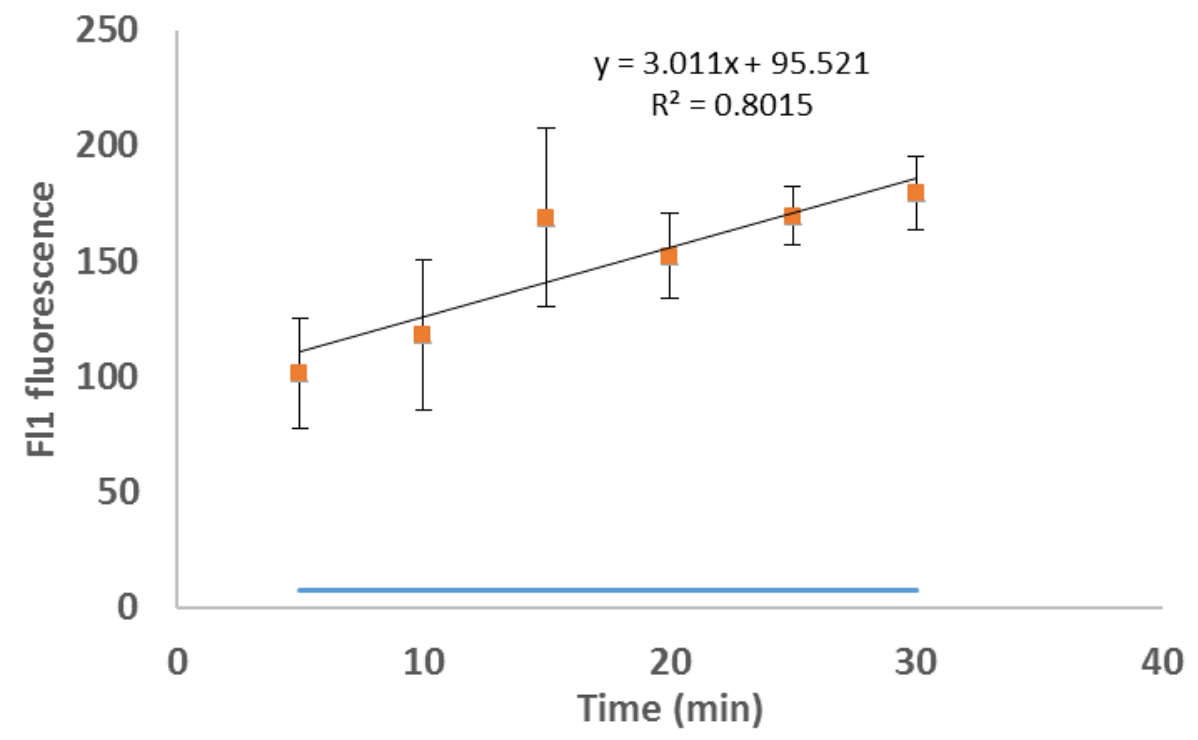

Supplementary figure 3: Mean internal Fl1 fluorescence of C. muelleri stained with FDA for 5, 10, 15, 20, 25 and 30 min (in seawater at room temperature). The black line represents the linear model of C. muelleri Fl1 fluorescence as a function of time of incubation. The Blue line represents the Fl1 fluorescence levels of C. muelleri (not stained). 


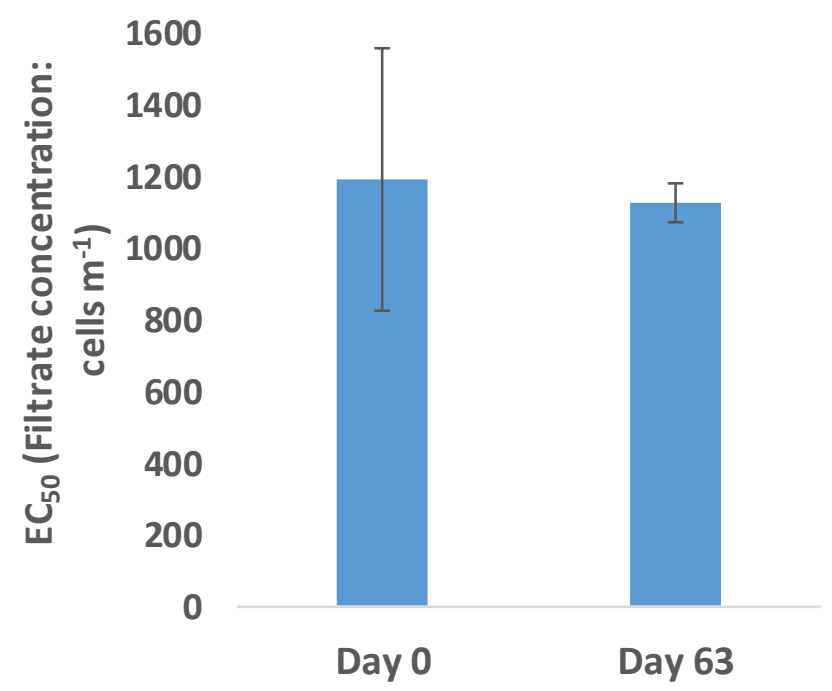

573

574 Supplementary figure 4: Example of the effect of storage on the allelopathic potency of filtrate of A. minutum CCMI1002. The 575 allelopathic potency $\left(E C_{50}\right)$ of the filtrate was measured on the fresh filtrate (Day 0) and on the filtrate stored for 63 days in a glass 576 tube in the dark at $5^{\circ} \mathrm{C}$. The culture used for the preparation of the filtrate was grown in L1 media in artificial seawater. The bioassay 577 was performed according to the standard bioassay procedure given in the manuscript. Error bars represent standard error of the $578 E C_{50}$. 